\section{УАК 622.279.5}

С. В. МАТКІВСьКИЙ, аспірант кафедри видобування нафти і газу (Івано-Франківський національний технічний університет нафти і газу), начальник відділу проєктування систем розробки родовищ вуглеводнів (Український науково-дослідний інститут природних газів, м. Харків), matkivskyi.sergey@ndigas.com.ua, https://orcid.org/0000-0002-4139-1381
S. MATKIVSKYI, PhD student at the department of oil and gas fields development (Ivano-Frankivsk national technical university of oil and gas), head of the hydrocarbon fields development planning department (Ukrainian scientific-research institute of natural gases, Harkiv), Ukraine matkivskyi.sergey@ndigas.com.ua, https://orcid.org/0000-0002-4139-1381

\title{
ВПЛИВ ЩІЛЬНОСТІ СІТКИ НАГНІТАЛЬНИХ СВЕРДЛОВИН НА РЕГУЛЮВАННЯ ПРОЦЕСУ ОБВОДНЕННЯ ГАЗОКОНДЕНСАТНИХ ПОКЛАДІВ ШЛЯХОМ НАГНІТАННЯ ДІОКСИДУ ВУГЛЕЦЮ
}

\author{
IMPACT OF THE WELL PLACEMENT DENSITY OF WATER FLOODING PROCESS CONTROL \\ BY INJECTION OF CARBON DIOXIDE
}

Використовуючи цифрову тривимірну модель газоконденсатного родовища, досліджено вплив щільності сітки нагнітальних свердловин на регулювання процесу обводнення родовища під час нагнітання діоксиду вуглецю в продуктивні поклади на межі початкового газоводяного контакту. Згідно з результатами моделювання встановлено, що видобуток пластової води зі збільшенням щільності сітки нагнітальних свердловин зменшується. У разі використання чотирьох нагнітальних свердловин для нагнітання діоксиду вуглецю в продуктивні поклади накопичений видобуток пластової води на кінець розробки становить 169,71 тис. м². Зі збільшенням щільності сітки нагнітальних свердловин до 16 одиниць накопичений видобуток пластової води скорочується до 0,066 м². Такий результат досягається завдяки повнішому охопленню діоксидом вуглецю периметра газоносності та створенню надійного штучного бар'єра між водою й природним газом, який забезпечує ефективне блокування просування пластових вод у газонасичені інтервали продуктивних горизонтів. Зниження активності водонапірної системи зумовлює стабільну експлуатацію видобувних свердловин упродовж тривалішого періоду дорозробки покладу. На основі результатів проведених розрахунків визначено максимальне значення кількості нагнітальних свердловин на момент прориву діоксиду вуглецю до видобувних свердловин, яке становить 6,41 (6) свердловин. Прогнозний ступінь вилучення природного газу для наведеного максимального значення кількості нагнітальних свердловин становить 64,05 \%, а в разі розроблення покладу на виснаження - 51,72 \%. Результати проведених досліджень свідчать про технологічну ефективність нагнітання діоксиду вуглецю в продуктивні поклади на межі початкового газоводяного контакту з метою зниження активності водонапірної системи та збільшення ступеня вилучення природного газу для умов конкретного покладу.

Ключові слова: 3D-модель родовища, газоконденсатний поклад, водонапірний режим, защемлений газ, нагнітання діоксиду вуглецю.

Using a 3D-model of a gas condensate field, the influence of the density of the grid of injection wells on the regulation of the process of flooding of the field when injecting carbon dioxide into productive reservoirs on the boundary of the initial gas-water contact is investigated. According to the simulation results, it was found that the water production cumulative decreases with an increase in the density of the grid of injection wells. In the case of using 4 injection wells to inject carbon dioxide into productive reservoirs, the water production cumulative is $169,71 \mathrm{th} . \mathrm{m}^{3}$. With an increase in the density of the grid of injection wells to 16 , the water production cumulative is reduced to $0,066 \mathrm{~m}^{3}$. This result is achieved due to a more complete coverage of the perimeter of gas content with carbon dioxide and the creation of a reliable artificial barrier between water and natural gas, due to which an effective blocking of the advancement of marginal waters into gas-saturated intervals of productive horizons is ensured. A decrease in the activity of the water drive system determines the stable operation of production wells for a long period of additional development of the reservoir. Based on the results of the calculations, the maximum value of the number of injection wells is 6,41 (6) wells. The predicted of natural gas recovery factor for the given maximum value of the number of injection wells is $64,05 \%$, and for depletion development it is $51,72 \%$. The results of the studies carried out indicate the technological efficiency of injecting carbon dioxide into productive reservoirs on the boundary of the initial gas-water contact in order to reduce the activity of the water-pressure system and increase of natural gas recovery factor for the conditions of a particular field.

Keywords: $3 D$-model of the field, gas condensate reservoir, water drive, trapped gas, injection of carbon dioxide.

\section{ВстуII}

Більшість родовищ України, з яких забезпечується основний видобуток вуглеводнів, перебуває в пізній стадії розробці та характеризується вибірковим обводненням продуктивних покладів і видобувних свердловин [3-4]. Унаслідок просування пластової води високопроникними пластами відбувається відтинання фронтом пластової води ділянок покладу з високою газонасиченістю, що зумовлює защемлення залишкових запасів газу $[5,9]$.

При розробці родовищ природних газів важливою є інформація щодо переміщення пластових і підошовних вод. На характер просування газоводяного контакту істотно впливає неоднорідність продуктивного розрізу, складеного 3 порід, що характеризуються мінливістю фільтраційноємнісних властивостейяк за товщиною,такізаплощею $[8,10]$. В міру виснаження пластової енергії відбувається підняття газоводяного контакту, що призводить до зменшення газонасиченої товщини пластів, появи води в продукції видобувних свердловин і зниження дебітів газу [16].

Визначення положення газоводяного контакту за водонапірного режиму розробки продуктивних покладів є важливим завданням контролю, без якого неможлива раціональна розробка родовища [19].

Під час проєктування раціональної системи розробки виснажених газових і газоконденсатних родовищ використовують різні технології підвищення коефіцієнтів вуглеводне- 
вилучення. Доцільність та ефективність вибраних методів і технологій залежить винятково від співвідношення необводненої та обводненої продуктивної площі родовища.

На основі результатів численних лабораторних досліджень розкрито механізм поведінки защемленого природного газу пластовою водою в пористому середовищі [13-17]. Використовуючи результати досліджень розроблено нові та вдосконалено наявні технології розробки родових за водонапірного режиму. Зважаючи на істотну неоднорідність покладів вуглеводнів як за площею, так і за товщиною, розроблені технології зазвичай малоефективні або їх не можливо реалізувати за результатами техніко-економічної оцінки. Характер розподілу фільтраційно-ємнісних властивостей колектора вносить істотну невизначеність у процес обгрунтування оптимальної технології розробки родовищ за таких умов.

На сьогодні перспективним є напрям підвищення вуглеводневилучення виснажених родовищ, для яких характерний водонапірний режим розробки з використанням невуглеводневих газів. Однією з успішних технологій підвищення вуглеводневилучення є технологія нагнітання діоксиду вуглецю в продуктивні поклади. Теоретичні та експериментальні дослідження процесу запомповування діоксиду вуглецю для витіснення залишкового газу підтверджують його технологічну ефективність [11, 18, 21, 25].

У працях [15, 23-24] наведено результати лабораторних досліджень з витіснення залишкового газу азотом, діоксидом вуглецю та димовими газами з горизонтальних моделей однорідного та неоднорідного пластів. Результати лабораторних досліджень свідчать про високу ефективність використання невуглеводневих газів для витіснення залишкового газу з продуктивних покладів. Однак, найвищий коефіцієнт вилучення природного газу отримано в експериментах із застосуванням у ролі агента нагнітання - діоксиду вуглецю.

Численними лабораторними та експериментальними дослідженнями підтверджено, що діоксид вуглецю добре розчиняється в пластових флюїдах (нафті, конденсаті й воді). Завдяки високій розчинності діоксиду вуглецю збільшується рухомість нафти й конденсату та водночас зменшується рухомість пластової води [12].

Результати гідродинамічного моделювання засвідчують, що завдяки запомповуванню діоксиду вуглецю приплив і просування пластової води стає контрольованим, що забезпечує набагато вищі коефіцієнти вуглеводневилучення [6-7,20].

Теоретичні та експериментальні дослідження процесу запомповування невуглеводневих газів для витіснення залишкового газу та сповільнення просування пластової води в продуктивні поклади підтверджують їхню ефективність, однак до сьогодні не досліджено проблему вибору агента нагнітання, який забезпечить найбільший ефект і за яких умов.

Результати досліджень свідчать про те, що кінцевий коефіцієнт вилучення газу під час запомповування невуглеводневих газів залежить від ступеня неоднорідності колектора як за товщиною, так і за площею, капілярних тисків на межі розділу двох фаз, щільності сітки нагнітальних свердловин та їхньої схеми розміщення на площі покладів.

Для вдосконалення наявних технологій розробки родовищ природних газів та підвищення кінцевого коефіцієнта вилучення газу шляхом запомповування діоксиду вуглецю в продуктивний поклад доцільно проводити додаткові дослідження з використанням інструментів гідродинамічного моделювання.

\section{Постановка проблеми}

Більшість родовищ вуглеводнів пристосована до водонапірних пластових систем. Коефіцієнти вилучення природного газу за водонапірного режиму становлять 70-85\%. Ураховуючи низький ступінь вилучення вуглеводнів, можна зробити висновок про те, що в процесі надходження пластової води в газонасичені горизонти защемлюються чималі об'єми природного газу [3-5, 9]. Зважаючи на гострий дефіцит вуглеводневої сировини в Україні, виникає необхідність у пошуку нових методів і технологій підвищення вуглеводневилучення з газових і газоконденсатних родовищ, для яких характерний водонапірний режим розробки. Для вдосконалення наявних технологій розробки родовищ вуглеводнів доцільно проводити додаткові дослідження, спрямовані на мінімізацію шкідливого впливу пластової води на процес видобування природного газу.

\section{Виклад основного матеріалу}

Для проведення комплексних досліджень 3 підвищення ступеня вилучення природного газу за водонапірного режиму та вдосконалення наявних технологій розробки родовищ використовували основні інструменти гідродинамічного моделювання Eclipse та Petrel компанії Schlumberger [14, 22].

Дослідження ефективності нагнітання діоксиду вуглецю в продуктивні поклади з метою регулювання фронту руху пластової води виконано на основі синтетичної тривимірної моделі газоконденсатного покладу. Запаси газу тривимірної моделі газоконденсатного покладу становлять 800 млн м ${ }^{3}$, товщина пласта - 15,4 м, пластовий тиск - 35 МПа, пластова температура $-358 \mathrm{~K}$, пористість становить 0,18 , коефіцієнт абсолютної проникності - 8,65·10-3 мкм² $^{2}$ коефіцієнт газонасиченості - 0,8.

Для відтворення фізичних процесів, що мають місце в пласті, у разі нагнітання невуглеводневих газів використано композиційну PVT-модель [1-2].

Газоконденсатний поклад розробляється на виснаження 3 використанням п'яти видобувних свердловин, які експлуатують 3 дебітом газу 50 тис. м³/добу. Відстань між видобувними свердловинами становить 400 м.

Дослідження проведено для запомповування діоксиду вуглецю в продуктивний поклад з використанням 4, 6, 8, 12, 16 свердловин, які рівномірно розміщені на межі початкового газоводяного контакту. Приймальність нагнітальних свердловин дорівнює 50 тис. $\mathrm{M}^{3} /$ добу.

На основі результатів моделювання здійснено аналіз основних технологічних показників розробки продуктивного покладу. Аналізуючи результати досліджень, потрібно звернути увагу на характер залежності динаміки пластового тиску в часі. Такий характер динаміки пластового тиску зумовлений відключенням видобувних свердловин у зв'язку з проривом діоксиду вуглецю або обводненням. Також істотний вплив на характер зміни пластового тиску має активність водонапірної системи. Завдяки надходженню пластової води в поклад відбувається часткова компенсація відборів вуглеводневої продукції.

Динаміку пластового тиску в часі під час запомповування діоксиду вуглецю в поклад для різної кількості нагнітальних свердловин наведено на рис. 1 .

За результатами проведених досліджень встановлено, що збільшення щільності сітки нагнітальних свердловин з чотирьох до восьми одиниць на момент прориву діоксиду вуглецю до видобувних свердловин не суттєво впливає на середній пластовий тиск у покладі, однак наступне збільшення кількості нагнітальних свердловин призводить до різкого збільшення пластового тиску. 
Розрахунки величини пластового тиску на момент прориву діоксиду вуглецю у видобувні свердловини для різної кількості нагнітальних свердловин та під час розробки покладу на виснаження наведено на табл. 1.

Аналізуючи залежність часу прориву діоксиду вуглецю до видобувних свердловин від кількості нагнітальних свердловин, можна зробити висновок про те, що збільшення щільності сітки нагнітальних свердловин з чотирьох до восьми свердловин призводить до збільшення часу прориву діоксиду вуглецю у видобувні свердловини із 44 до 47 місяців. Наступне ущільнення сітки нагнітальних свердловин з восьми до 16 свердловин призводить до різкого зменшення часу прориву із 47 до 34 місяців.

На підставі результатів моделювання визначено, що збільшення кількості нагнітальних свердловин призводить до зменшення накопиченого видобутку природного газу. Пояснюється отриманий результат моделювання розробки продуктивного покладу зменшенням тривалості періоду експлуатації видобувних свердловин до моменту прориву діоксиду вуглецю у свердловини в разі збільшення щільності сітки нагнітальних свердловин.

Динаміку накопиченого видобутку природного газу під час нагнітання діоксиду вуглецю для різної кількості нагнітальних свердловин наведено на рис. 2 .

Аналізуючи основні технологічні показники розробки, варто зазначити обсяги видобутку пластової води залежно від щільності сітки нагнітальних свердловин у разі нагнітання діоксиду вуглецю на початковому газоводяному контакті. Згідно з отриманими результатами встановлено, що видобуток пластової води зі збільшенням кількості нагнітальних свердловин зменшується. У разі використання чотирьох свердловин для запомповування діоксиду вуглецю в продуктивний поклад накопичений видобуток пластової води становив 169,71 тис. м $^{3}$. Зі збільшенням кількості нагнітальних свердловин до 16 одиниць накопичений видобуток води на кінець розробки покладів зменшується до $0,066 \mathrm{~m}^{3}$.

Динаміку накопиченого видобутку пластової води під час нагнітання діоксиду вуглецю для різної кількості нагнітальних свердловин наведено на рис. 3 .

На основі аналізу основних технологічних показників розробки продуктивного покладу на виснаження та із запомповуванням діоксиду вуглецю встановлено, що впровадження технології нагнітання невуглеводневого газу на межі газоводяного контакту призводить до скорочення обсягів видобутку пластової води. Завдяки нагнітанню невуглевод- невого газу створюється штучний бар'єр, який призводить до ефективного блокування пластової води.

За результатами моделювання здійснено розрахунок величини коефіцієнтів вилучення природного газу на момент прориву діоксиду вуглецю до видобувних свердловин за величиною накопиченого видобутку пластової води. Розрахунки величини коефіцієнтів вилучення природного газу наведено в табл. 2.

Згідно з результатами статистичного опрацювання розрахункових даних визначено максимальне значення кількості нагнітальних свердловин для нагнітання діоксиду вуглецю в поклад. Максимальне значення кількості нагнітальних свердловин на момент прориву діоксиду вуглецю до видобувних свердловин становить 6,41 (6) свердловин. Прогнозний коефіцієнт вилучення газу для наведеного оптимального значення кількості нагнітальних свердловин становить $63,52 \%$. У разі розробки газоконденсатного покладу на виснаження кінцевий коефіцієнт вилучення газу за цих умов становить $51,72 \%$.

Таблиця 1. Результати розрахунків величини пластового тиску на момент прориву діоксиду вуглецю у видобувні свердловини для різної кількості нагнітальних свердловин та при розробці покладу на виснаження

\begin{tabular}{|c|c|c|}
\hline \multirow{2}{*}{$\begin{array}{c}\text { Кількість } \\
\text { свердловин }\end{array}$} & \multicolumn{2}{|c|}{ Пластовий тиск, МПа } \\
\cline { 2 - 3 } & Виснаження & Нагнітання \\
\hline 4 & 29,37 & 29,87 \\
\hline 6 & 29,20 & 29,90 \\
\hline 8 & 29,02 & 29,93 \\
\hline 12 & 29,73 & 30,78 \\
\hline 16 & 30,20 & 31,56 \\
\hline
\end{tabular}

Таблиця 2. Результати розрахунків коефіцієнтів вилучення природного газу на момент прориву діоксиду вуглецю до видобувних свердловин від кількості нагнітальних свердловин

\begin{tabular}{|c|c|}
\hline $\begin{array}{c}\text { Кількість } \\
\text { свердловин }\end{array}$ & Коефіцієнт вилучення природного газу, \% \\
\hline 4 & 41,48 \\
\hline 6 & 43,24 \\
\hline 8 & 43,37 \\
\hline 12 & 37,83 \\
\hline 16 & 32,27 \\
\hline
\end{tabular}

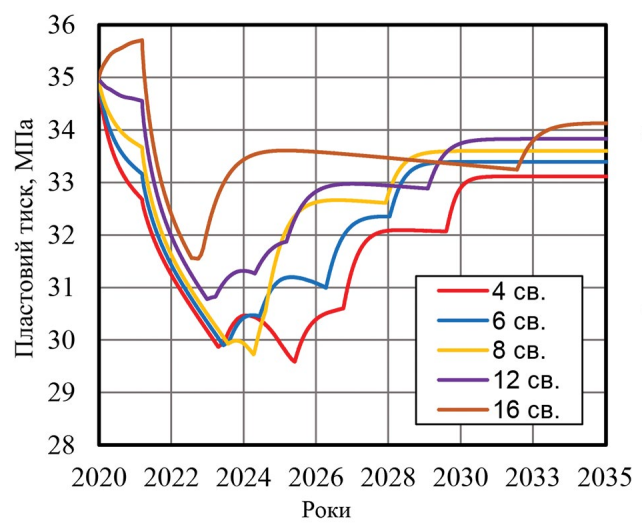

Рис. 1. Динаміка пластового тиску в часі при запомповуванні діоксиду вуглецю для різної кількості нагнітальних свердловин

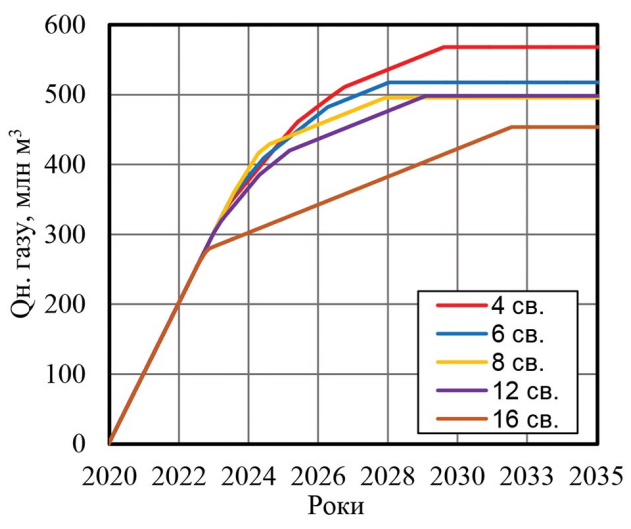

Рис. 2. Динаміка накопиченого видобутку природного газу під час нагнітання діоксиду вуглецю для різної кількості нагнітальних свердловин

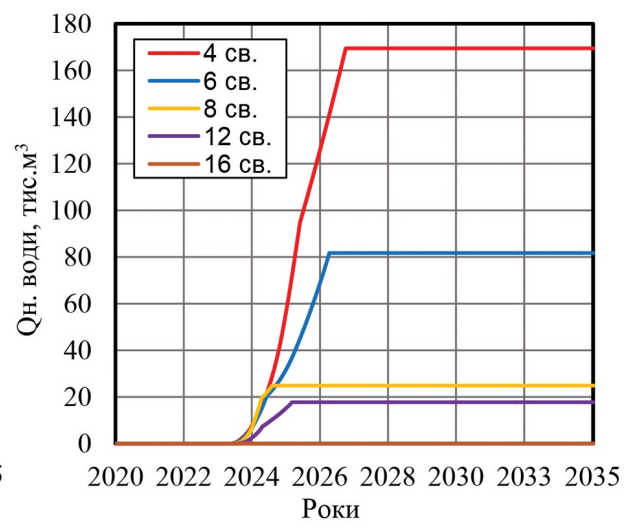

Рис. 3. Динаміка накопиченого видобутку пластової води для різної кількості нагнітальних свердловин під час нагнітання діоксиду вуглецю 


\section{Висновки}

Використовуючи 3D-модель газоконденсатного покладу, проведено дослідження впливу щільності сітки нагнітальних свердловин на регулювання процесу обводнення шляхом нагнітання діоксиду вуглецю на межі початкового газоводяного контакту. Згідно з результатами моделювання в разі запомповування діоксиду вуглецю спостерігається сповільнення просування пластової води в газонасичені горизонти, що зумовлює більшу надійність видобувних можливостей продуктивного покладу.

На основі результатів проведених розрахунків визначено максимальне значення кількості нагнітальних свердловин на момент прориву діоксиду вуглецю до видобувних свердловин, яке становить 6,41 (6) свердловин. Прогнозний ступінь вилучення газу для наведеного максимального значення кількості нагнітальних свердловин становить 64,05 \%, а при розробці газоконденсатного покладу на виснаження - 51,72 \%.

Результати проведених досліджень свідчать про технологічну ефективність запомповування діоксиду вуглецю на межі початкового газоводяного контакту для сповільнення просування пластової води в продуктивний поклад і збільшення кінцевого коефіцієнта вуглеводневилучення.

Практична реалізація систем оптимізації розробки газоконденсатних родовищ у широкому розумінні проблеми дасть змогу суттєво інтенсифікувати процес видобутку газу й конденсату та вийти на світовий рівень розв'язання поставленої проблеми.

\section{ЛІТЕРАТУРА}

1. Бурачок О. В., Першин Д. В., Матківський С. В., Бікман С. С. Кондрат О. Р. Особливості відтворення рівняння стану газоконденсатних сумішей за умови обмеженої вхідної інформації/Розвідка та розробка нафтових і газових родовищ. -2020 . - № 1 (74). - С. 82-88.

2.Бурачок О. В.,Периин Д. В.,Матківський С. В.,Кондрат О. Р. Дослідження межі застосування PVT-моделі “чорної нафти” для моделювання газоконденсатних покладів//Мінеральні ресурси України. - 2020. - № 2. - С. 43-48.

3. Довідник 3 нафтогазової справи/В. С. Бойко, Р. М. Кондрат, Р. С. Яремійчук. - К.: Львів, 1996. - 620 с.

4. Кондрат О.Р. Підвищення газовилучення з газових родовищ при водонапірному режимі шляхом регулювання надходження пластової води і видобутку защемленого газу/О. Р. Кондрат, Р. М. Кондрат//Нафтогазова галузь України. - 2019. - № 4. - С. 21-26.

5. Кондрат P. М. Активний вплив на процеси розробки родовищ природних газів з водонапірним режимом для збільшення газоконденсатовилучення//Наука та інновації. - 2005. - Т. 1. - № 5. - С. 12-23.

6. Матківський С. В., Кондрат О. Р. Вплив тривалості періоду нагнітання діоксиду вуглецю на газовилучення в умовах прояву водонапірного режиму//Тези V Міжнародної науково-практичної конференції. - Осло, Норвегія, 2020. - С. 25-27.

7. Матківський С. В., Кондрат О. Р. Підвищення вуглеводневилучення з обводнених газоконденсатних покладів шляхом нагнітання діоксиду вуглецю//Science, society, education: topical issues and development prospects. Abstracts of the 10th International scientific and practical conference. SPC "Sci-conf.com.ua”.Kharkiv, Ukraine. - 2020 - P.96-101.

8. Матківський С. В., Кондрат О. Р., Хайдарова Л. І. та ін. Дослідження впливу незначного прояву водонапірної системи на достовірність матеріального балансу колекторів//Розвідка та розробка нафтових і газових родовищ. - 2020. - № 2 (75). - С. 43-51.

9. Обводнення газових i нафтових свердловин/В. С. Бойко, Р. В. Бойко, Л. М. Кеба, О. В. Семінський. 1-е вид. - Київ: Міжнародна економічна фундація, 2006. - $791 \mathrm{c.}$

10. Тер-Саркисов Р. М. Разработка месторождений природных газов. - М.: Недра, 1999. - 659 с.

11. Тер-Саркисов Р. М. Технология закачки азота для добычи защемленного и низконапорного газа//Газовая промышленность. 2006. - № 4. - C. 24-26.

12. Al-Hashami A., Ren S. R. and Tohid B.: CO2 Injection for Enhanced Gas Recovery and Geo-Storage Reservoir Simulation and Eco- nomics, Institute of Petroleum Engineering, Herriot-Watt University, SPE 94129, SPE Europec/EAGE Annual Conference and Exhibition held in Madrid, Spain, 13-16 June, 2005. - P. 1-7.

13. Chierici G. L., Ciocc G. M., and 1ong G. (1963). Experimental Research on Gas Saturation Behind the Water Front in Gas Reservoirs Subjected to Water Drive, Proc, Sixth World Pet. Cong., Frankfurt (1963) Sec IV Paper 17-PD6. 483-498. WPC-10134.

14. ECLIPSE. [2020]. ECLIPSE Technical Description. Version 2020.1 (C) Schlumberger, 2020. - 1078 p.

15. Enhanced Gas Recovery: Effect of Reservoir Heterogeneity on Gas-Gas Displacement. S. S. K. Sim, A. T. Turta, A. K. Singhal, B. F. Hawkins. Canadian International Petroleum Conference. 16-18 June. Calgary, Alberta. 2009.

16. Gamal M., Khairy M., El-Banbi A. H., Saad S. M.: An Approach for Determination of the Economically Optimal Production Controlling Parameters from Water Drive Oil Reservoirs, SPE Kingdom of Saudi Arabia Annual Technical Symposium and Exhibition, 25-28 April, Dammam, Saudi Arabia, 2016.

17. Geffen T. M., Parrish D. R., Haynes C. W., and Morse R. A. Efficiency of Gas Displacement from Porous Media by Liquid Flooding. Trans., AIME (1952) 195, 1952. - C. 29-38.

18. Kondrat O., Matkivskyi S. Research of the influence of the pattern arrangement of injection wells on the gas recovery factor when injecting carbon dioxide into reservoir. Technology and system of power supply. - 2020. - № 5/1 (55). - C. 1-17.

19. Kondrat $O . R$., Kondrat R.M. Investigation of regularities of trapped gas recovery processes from watered gas fields with homogeneous and macro heterogeneous reservoirs/Mining of mineral deposits, Taylor\&Francis Group, London, Uk, 2014. - P. 303-309.

20. Kryvulya S., Matkivskyi S., Kondrat O., Bikman Ye. Approval of the technology of carbon dioxide injection into the V-16 water driven reservoir of the Hadiach field (Ukraine) under the conditions of the water pressure mode. Technology and system of power supply. -2020 . - № 6/1 (56). - C. 13-18.

21. Mamora D. D. and Seo J. G. Enhanced Gas Recovery by Carbon Dioxide Sequestration in Depleted Gas Reservoirs, SPE Technical Conference and Exhibition, 29 Sept.-2 Oct. 2002, San Antonio, Texas. P. 1-9.

22. Petrel. Help. Version 2019.2. Mark of Schlumberger.

23. Sim S. S. K., Turta A. T., Singhai A. K. and Hawkins B. F. Enhanced Gas Recovery: Factors Affecting Gas-Gas Displacement Efficiency, Canada International petroleum Conference, June 17-19, Calgari, Alberta, Canada. 2008. - P. 1-14.

24. SPE 113468. Enhanced Gas Recovery and CO2 Sequestration by Injection of Exhaust Gases From Combustion of Bitumen. Steve S. K. Sim, Patrick Brunelle, Alex T. Turta and Ashok K. Singhal. SPE Symposium on Improved Oil Recovery. 20-23 April, Tulsa, Oklahoma, USA. 2008.

25. Turta A. T., Sim S. S. K., Singhai A. K. and Hawkin B. F. (2008). Basic Investigations on Enhanced Recovery by Gas - Gas Displacement, Journal of Canada Petroleum Technology, Volume 47, Number 10 , Alberta, Canada, 2008. - P. 1-6.

\section{REFERENCES}

1. Burachok O. V., Pershin D. V., Matkivskyi S. V., Bikman Ye.S., Kondrat $O$. R. Features of reproduction of the equation of state of gas condensate mixtures under the condition of limited input information// Rozvidka ta rozrobka naftovykh i hazovykh rodovychsh. - № 1 (74). 2020. - P. 82-88. (In Ukrainian).

2. Burachok O.V., Pershin D. V., Matkivskyi S.V., Kondrat O.R. Investigation of the limits of application of PVT-model of "black oil" for modeling of gas condensate reservoirs//Mineralni resursy Ukrainy. 2020. - № 2. - P. 43-48. (In Ukrainian).

3. Handbook of oil and gas/V. S. Boiko, R. M. Kondrat, R. S. Yaremiichuk. - Kyiv: Lviv, 1996. - 620 p. (In Ukrainian).

4. Kondrat $O$. R., Kondrat $R$. M. Increase of gas recovery from gas fields under water drive by regulating the supply of contour formation water and production of trapped gas//Naftohazova haluz Ukrainy. 2019. - № 4. - P. 21-26. (In Ukrainian).

5. Kondrat R. M. Active influence on the processes of development of natural gas fields with water drive to increase gas condensate recovery// Nauka ta innovatsii. - 2005. - Vol. 1. - № 5. - P. 12-23. (In Ukrainian).

6. Matkivskyi S. V., Kondrat $O$. R. Influence of the duration of the period of carbon dioxide injection on gas recovery in the conditions of manifestation of the water drive//Tezy V Mizhnarodnoi naukovo-praktychnoi konferentsii. - Oslo, Norvehiia, 2020. - P. 25-27. (In Ukrainian). 
7. Matkivskyi S. V., Kondrat O.R. Increase of hydrocarbon recovery from flooded gas condensate reservoirs by injection of carbon dioxide//Science, society, education: topical issues and development prospects. Abstracts of the 10th International scientific and practical conference. SOC "Sci-conf.com.ua”. Kharkiv, Ukraine. 2020. - P. 96-101. (In Ukrainian).

8. Matkivskyi S. V., Kondrat O. R., Khaidarova L. I. and others. Investigation of the influence of insignificant manifestation of the water pressure system on the reliability of the material balance of reservoirs// Rozvidka ta rozrobka naftovykh i hazovykh rodovyshch. - 2020. - № 2 (75). - P. 43-51. (In Ukrainian).

9. Flooding of gas and oil wells/V. S. Boiko, R. V. Boiko, L. M. Keba, O. V. Seminskyi. 1st ed. - Kyiv: Mizhnarodna ekonomichna fundatsiia, 2006. - 791 p. (In Ukrainian).

10. Ter-Sarkisov R. M. Development of natural gas fields. - Moskva: Nedra, 1999. - 659 p. (In Russian).

11. Ter-Sarkisov R. M. 2006. Nitrogen injection technology for the production of trapped and low-pressure gas//Gazovaja promyshlennost. - 2006. - № 4. - P. 24-26. (In Russian).

12. Al-Hashami A., Ren S. R. and Tohid B.: CO2 Injection for Enhanced Gas Recovery and Geo-Storage Reservoir Simulation and Economics, Institute of Petroleum Engineering, Herriot-Watt University, SPE 94129, SPE Europec/EAGE Annual Conference and Exhibition held in Madrid, Spain, 13-16 June, 2005. - P. 1-7.

13. Chierici G. L., Ciocc G. M., and 1ong G. (1963). Experimental Research on Gas Saturation Behind the Water Front in Gas Reservoirs Subjected to Water Drive, Proc, Sixth World Pet. Cong., Frankfurt (1963) Sec IV Paper 17-PD6. 483-498. WPC-10134.

14. ECLIPSE. [2020]. ECLIPSE Technical Description. Version 2020.1 (C) Schlumberger, 2020. - 1078 p.

15. Enhanced Gas Recovery: Effect of Reservoir Heterogeneity on Gas-Gas Displacement. S. S. K. Sim, A. T. Turta, A. K. Singhal, B. F. Hawkins. Canadian International Petroleum Conference. 16-18 June. Calgary, Alberta. 2009.

16. Gamal M., Khairy M., El-Banbi A. H., Saad S. M.: An Approach for Determination of the Economically Optimal Production Controlling Parameters from Water Drive Oil Reservoirs, SPE Kingdom of Saudi Arabia Annual Technical Symposium and Exhibition, 25-28 April, Dammam, Saudi Arabia, 2016.

17. Geffen T. M., Parrish D. R., Haynes C. W., and Morse R. A. Efficiency of Gas Displacement from Porous Media by Liquid Flooding. Trans., AIME (1952) 195, 1952. - C. 29-38.

18. Kondrat O., Matkivskyi S. Research of the influence of the pattern arrangement of injection wells on the gas recovery factor when injecting carbon dioxide into reservoir. Technology and system of power supply. -2020 . № 5/1 (55). - C. 1-17.

19. Kondrat O. R., Kondrat R. M. Investigation of regularities of trapped gas recovery processes from watered gas fields with homogeneous and macro heterogeneous reservoirs/Mining of mineral deposits, Taylor \& Francis Group, London, Uk, 2014. - P. 303-309.

20. Kryvulya S., Matkivskyi S., Kondrat O., Bikman Ye. Approval of the technology of carbon dioxide injection into the V-16 water driven reservoir of the Hadiach field (Ukraine) under the conditions of the water pressure mode. Technology and system of power supply. -2020 . № 6/1 (56). - C. 13-18.

21. Mamora D. D. and Seo J. G. Enhanced Gas Recovery by Carbon Dioxide Sequestration in Depleted Gas Reservoirs, SPE Technical Conference and Exhibition, 29 Sept.-2 Oct. 2002, San Antonio, Texas. P. 1-9.

22. Petrel. Help. Version 2019.2. Mark of Schlumberger.

23. Sim S. S. K., Turta A. T., Singhai A. K. and Hawkins B. F. Enhanced Gas Recovery: Factors Affecting Gas-Gas Displacement Efficiency, Canada International petroleum Conference, June 17-19, Calgari, Alberta, Canada. 2008. - P. 1-14.

24. SPE 113468. Enhanced Gas Recovery and CO2 Sequestration by Injection of Exhaust Gases From Combustion of Bitumen. Steve S.K. Sim, Patrick Brunelle, Alex T. Turta and Ashok K. Singhal. SPE Symposium on Improved Oil Recovery. 20-23 April, Tulsa, Oklahoma, USA. 2008.

25. Turta A. T., Sim S. S. K., Singhai A. K. and Hawkin B. F. (2008) Basic Investigations on Enhanced Recovery by Gas - Gas Displacement, Journal of Canada Petroleum Technology, Volume 47, Number 10 , Alberta, Canada, 2008. - P. 1-6.

Рукопи с отримано 8.02 .2021$.
3 метою подальшого підвищення наукового рейтингу журналу та його дописувачів варто звернути увагу на наступне:

1. Кожна публікація не англійською мовою супроводжується анотацією англійською мовою обсягом не менш як 1800 знаків (з ключовими словами). Якщо видання не є повністю українськомовним, кожна публікація не українською мовою супроводжується анотацією українською мовою обсягом не менш як 1800 знаків (з ключовими словами, ураховуючи пропуски).

2. Вимоги до анотацій англійською мовою: інформативність (без загальних слів); змістовність (відображення основного змісту статті та результатів досліджень); застосування термінології, характерної для іноземних спеціальних текстів; єдність термінології в межах анотації; без повторення відомостей, що містяться в заголовку статті.

3. Прізвища авторів статей надаються в одній з прийнятих міжнародних систем транслітерації (з української - відповідно до Постанови Кабінету Міністрів України № 55 від 27.01.2010 "Про впорядкування транслітерації українського алфавіту латиницею", з російської - відповідно до “Системы транслитерации Библиотеки конгресса США”). Зазначення прізвища в різних системах транслітерації призводить до створення в базі даних різних профілів (ідентифікаторів) одного автора.

4. Для повного й коректного створення профілю автора дуже важливо наводити місце його роботи. Дані про публікації автора використовуються для отримання повної інформації щодо наукової діяльності організацій і загалом країни. Застосування в статті офіційної, без скорочень, назви організації англійською мовою запобігатиме втраті статей у системі аналізу організацій та авторів. Бажано вказувати в назві організації ії відомство за належністю.

5. В аналітичній системі SCOPUS потрібні пристатейні списки використаної літератури латиницею. Можливості SCOPUS дають змогу проводити такі дослідження: за посиланнями оцінювати значення визнання робіт конкретних авторів, науковий рівень журналів, організацій і країн загалом, визначати актуальність наукових напрямів і проблем. Стаття з представленим списком літератури демонструє професійний кругозір та якісний рівень досліджень їі авторів.

6. Правильний опис джерел, на які посилаються автори, є запорукою того, що цитовану публікацію буде враховано в процесі оцінювання наукової діяльності ії авторів, а отже й організації, регіону, країни. За цитуванням журналу визначається його науковий рівень, авторитетність тощо.Тому найважливішими складниками в бібліографічних посиланнях є прізвища авторів і назви журналів. В опис статті треба вносити всіх авторів, не скорочуючи їхньої кількості. Для уникнення неточностей в ідентифікації авторства й визначення персональних метрик (показників) бібліометрії авторам наукових публікацій потрібно використовувати персональні коди ORCID.

7. Для українсько- та російськомовних статей з журналів, збірників, матеріалів конференцій структура бібліографічного опису така: автори (транслітерація), переклад назви статті англійською мовою, назва джерела (транслітерація), вихідні дані, у дужках мова оригіналу, ідентифікатор DOI.

8. Список використаної літератури (References) для SCOPUS та інших закордонних баз даних наводиться повністю окремим блоком, повторюючи список літератури до українсько- та російськомовної частини незалежно від того, містяться в ньому чи ні іноземні джерела. Якщо в списку є покликання на іноземні публікації, їх повністю повторюють у списку, який створюють у латинському алфавіті.

Рукопис статті до редакції автори подають зі своїми підписами. 